\title{
When online student numbers double during a pandemic
}

\author{
Nicholas Bowskill \\ University of Derby, UK \\ David Hall \\ University of Derby, UK \\ Lucy Hutchinson \\ University of Derby, UK \\ Melody Harrogate \\ University of Derby, UK
}

Keywords: podcasts; pandemic; group work; globalised learning; learning design; Covid19.

\section{The challenge}

What can you do when an online professional development module sees student numbers double? What effective but safe changes can you make to course design at short notice when both tutors and participants are working from home? This paper tackles learning design for large online groups during an educational crisis.

Innovative $21^{\text {st }}$ Century Teaching is an online professional development module delivered by the University of Derby. The aim is to model and promote student-centred learning within a globalised educational environment.

Participants in this postgraduate module are practising teachers from around the world. The module has been delivered twice in the context of the global pandemic. During the first quarter of 2020, it was delivered to 75 teachers and again in the first quarter of 2021 , to 149 teachers across four continents. 


\section{The response}

Tutoring was done from home on both occasions. One tutor covered the module and three others joined to mark final assessments. Key changes for the increased numbers were:

- A module podcast.

- Small group bases.

- Use of teacher-testimonies via global providers.

- Reflecting together on educational experiences of the pandemic.

\section{A module podcast}

Podcasts can be accessed at anytime and anywhere (Ro and Villarreal, 2021). Use of podcasts can increase efficiency and impact positively on practice (Malecki et al., 2019). Podcasts improve reflection and support community development when shared in groups (Forbes, 2011).

Participants already create podcasts as part of this module. They give their initial conceptions of $21^{\text {st }}$ Century Teaching and their podcasts are shared and discussed in social learning forums. This develops digital literacy, creates greater inclusion, and extends the concept of student voice and audio content into collaborative learning. Hearing human voices, diverse accents, and different genders in a globally distributed group supports diversity and develops cultural intelligence.

For this larger cohort, we added a weekly module podcast created by the tutor to humanise teaching and add value by offering mini-lectures, each lasting six to eight minutes. Audio content covered unit topics and overviewed assessment tasks. New episodes were shared on the Soundcloud podcasting platform and the audio file was posted on Blackboard for those with technical or local access issues. Of the 14 episodes produced, numbers one to seven each had over 100 plays on Soundcloud. The next four episodes each had over 60 plays and the last three episodes averaged 15 plays; however, the last three weeks do typically see a switch of student attention towards assessments. 


\section{Small group bases}

Large cohorts can depersonalise the experience of learning. For example, Massive Open Online Courses (MOOCs) often experience this phenomenon with difficulties maintaining learning relationships over time (Sanz-Martínez et al., 2019). Membership of groups can increase motivation and provide emotional support (Haslam et al., 2009). Peer-learning can be an effective development strategy (Dawson et al., 2014).

For this larger cohort, participants were organised into five online group bases. Each group had its own space within each unit and group membership remained constant throughout the module. Each group had approximately 30 members selected randomly at the start and listed in the main community forum. Groups were large enough to maintain an active dialogue across time zones and, over the 10-week period, they were still manageable for tutoring.

Participants created and shared a range of materials as part of different unit activities. They discussed content and the experiential activities were evaluated for transfer into participants' local practice.

\section{Use of teacher-testimonies via global providers}

Non-Governmental Organisations (NGOs) such as UNESCO, UNICEF and The World Bank play a key role during educational emergencies, including the Covid-19 pandemic. As trusted providers, NGOs provided webinars, case-studies, and research for schools around the world coping with closures and disruption during the pandemic. Unfortunately, teachers are often too busy or unaware of these resources.

We identified specific NGO collections relevant to teaching in the pandemic such as those from $\underline{O E C D}$. Participants were given a set of teacher-testimonies about coping during the pandemic. These self-created videos formed a set of case studies covering a range of contexts and responses. An archived set of webinars for teachers, given by NGOs, were also provided in the module.

Activities required participants to select items relevant to their practice and interests. Individuals then shared and explained their choices in groups. This activity connected our 
practitioners with a wider group of teachers hosted by trusted NGOs. This raised awareness of the availability and relevance of these resources. Participants also experienced a collaborative approach to resource evaluation as a pedagogical model.

\section{Reflecting on educational experiences of the pandemic}

Resilience is the ability to bounce-back from adversity (Smith et al., 2010). The pandemic was an educational, personal, and professional crisis and reflecting together on practitioner-challenges can therefore be a useful resource for teachers' resilience, practice, and well-being (Le Cornu, 2013).

We added an activity to support participants to discuss experiences of teaching during the pandemic. Participants shared what worked and identified common concerns. The activity simultaneously provided diverse coping strategies which had been tested in practice. This supported resilience through sharing, dialogue, and a growing sense of belonging.

Webinar sessions measured sense of belonging asking participants to respond in the chat box by posting a number between one and five (where one is a strong sense of belonging and five is none), with most posting one or two. Opportunities for educators to reflect on their pandemic experience with other professionals are rare. The module provided a safe space for participants to share success stories and offer mutual support.

\section{Recommendations}

Emails and forum comments suggested the rapid re-design was effective in coping with the doubling of student numbers. We modelled online learning activities while exploring, sharing, and creating digital resources together. We humanised tutoring and personalised learning with a module podcast. Several participants reported introducing podcasting into their practice while the course was still running.

We supported socialisation with small group bases. We raised awareness and evaluated global resources together. We supported resilience by relating participants' experiences of teaching during the pandemic with the experience of other practitioners via NGO sites. We reflected collaboratively on content and activities. In short, the re-design worked under the toughest test of a large globally distributed group of educators undergoing a fully online 
professional development module during a pandemic. Above all, we recommend participants create and share digital objects as representations of their views in order to make thinking visible and as an effective means to facilitate discussion and belonging.

\section{References}

Dawson, P., van der Meer, J., Skalicky, J. and Cowley, K. (2014) 'On the effectiveness of Supplemenetal Instruction: a systematic review of Supplemental Instruction and Peer-Assisted Study Sessions literature between 2011-2010', Review of Educational Research, 20(10), pp.1-31. https://doi.org/10.3102/0034654314540007.

Forbes, D. (2011) 'Beyond lecture capture: student-generated podcasts in teacher education', Waikato Journal of Education, 16(1), pp.51-64. Available at: https://core.ac.uk/download/pdf/44289802.pdf (Accessed: 9 September 2021).

Haslam, S. A., Jetten, J., Postmes, T. and Haslam, C. (2009) 'Social identity, health and well-being: an emerging agenda for Applied Psychology', Applied Psychology, 58(1), pp.1-23. https://doi.org/10.1111/j.1464-0597.2008.00379.x.

Le Cornu, R. (2013) 'Building early career teacher resilience: the role of relationships', Australian Journal of Teacher Education, 38(4), p.1. Available at: https://files.eric.ed.gov/fulltext/EJ1013933.pdf (Accessed: 9 September 2021).

Malecki, S. L., Quinn, K. L., Zilbert, N., Razak, F., Ginsburg, S., Verma, A. A. and Melvin, L. (2019) 'Understanding the use and perceived impact of a medical podcast: qualitative study', JMIR Med Educ, 5(2), e12901. https://doi.org/10.2196/12901.

Ro, K. and Villarreal, J. (2021) 'Development of interprofessional collaborative podcasts to introduce electrocardiographic fundamentals', The Journal for Nurse Practitioners, 17(3), pp.326-328. https://doi.org/10.1016/i.nurpra.2020.11.002.

Sanz-Martínez, L., Er, E., Martínez-Monés, A., Dimitriadis, Y. and Bote-Lorenzo, M. L. (2019) 'Creating collaborative groups in a MOOC: a homogeneous engagement 
grouping approach', Behaviour \& Information Technology, 38(11), pp.1107-1121. https://doi.org/10.1080/0144929X.2019.1571109.

Smith, B. W., Tooley, E. M., Christopher, P. J. and Kay, V. S. (2010) 'Resilience as the ability to bounce back from stress: a neglected personal resource?', The Journal of Positive Psychology, 5(3), pp.166-176.

https://doi.org/10.1080/17439760.2010.482186.

\section{Author details}

Nicholas Bowskill is a Senior Fellow of the Higher Education Academy and Senior Lecturer in Education (UDOL) at University of Derby. His research interests relate to technologysupported pedagogy, Constructionist theory, and generative digital practices.

David Hall is a Senior Lecturer in Education and leads the Leadership \& Management pathway for the MA Education programme (online) at the University of Derby. He researches educational management in general and has a specific interest in criteriabased assessment using rubrics.

Lucy Alucia Hutchinson is a Senior Fellow of the Higher Education Academy and Senior Lecturer in Education, University of Derby Online Learning (UDOL). Her research interests relate to Inclusion, disability, inclusive student engagement in online learning, with a special interest in narrowing the achievement gap as part of inclusion.

Melody Harrogate is a Programme Leader for the MA Education Part time on campus, UDOL, and International Partners. She is a Senior Lecturer in Education and leads the Leadership \& Management pathway for the MA Education programme on campus at the University of Derby. Her research includes educational leadership and quality management, and she is especially interested in how we learn, and real world learning. 